\title{
The Effect of Parental Environment Quality and Participation in Early Childhood Education on Children's Character
}

\author{
Mustika Dewanggi* \\ Department of Family and \\ Consumer Sciences, \\ Faculty of Human Ecology, \\ Bogor Agricultural University
}

\author{
Dwi Hastuti \\ Department of Family and \\ Consumer Sciences, \\ Faculty of Human Ecology, \\ Bogor Agricultural University \\ Tin Herawati \\ Department of Family and \\ Consumer Sciences, \\ Faculty of Human Ecology, \\ Bogor Agricultural University
}

*Corresponding author: dewanggimustika@gmail.com

\begin{abstract}
This study aims to analyze the effect of parental environment quality and participation in early childhood education on children's character. A sample in this study was randomly selected (random sampling) involving 100 respondents. Data were collected through interviews and observation techniques with the help of questionnaires. Data were analyzed with descriptive analysis, independent t-test, and regression test. The results showed that parental environment quality in which their children did not attend early childhood education was better than that whose children attended early childhood education. The results showed that there was a significant effect of parental environment quality on children's character, and there was no significant effect of participation in early childhood education on children's character.
\end{abstract}

Keywords: parental environment quality, participation in early childhood education, character.

Abstrak

Penelitian ini bertujuan untuk mengetahui pengaruh kualitas lingkungan pengasuhan dan keikutsertaan pendidikan anak usia dini terhadap pembentukan karakter anak. Pemilihan tempat dilakukan secara purposive di Kota dan Kabupaten Bogor. Penarikan contoh pada penelitian ini dipilih secara acak (random sampling) yang melibatkan 100 responden. Pengambilan data dilakukan melalui tekhnik wawancara dan observasi dengan bantuan kuesioner. Data dianalisis dengan análisis deskriptif, uji independent t-test, uji hubungan, dan uji regresi. Hasil penelitian menunjukan bahwa terdapat pengaruh yang signifikan dari jenis kelamin, usia anak, usia ibu, status bekerja ibu, dan kualitas lingkungan pengsuhan terhadap pembentukan karakter anak.

Kata kunci: kualitas lingkungan pengasuhan, keikutsertaan pendidikan anak usia dini, karakter anak. 


\section{Introduction}

Crime statistics in Indonesia on 2014 indicated that there was an increase in criminal activity from 2012 until 2013 (BPS 2014). Conditions of the increasing indicate the decline in the nation's character. The character building in an individual needs to be done from an early age and it will provide long-term impact to the lives of children when they grow up (Megawangi 2009). The character need to build from an early age which can be realized through the role of parents in providing a positive nurturing environment. Based on the research results, the environment quality of good parenting can produce a better social emotional development of children (Bhat \& Aminabhavi 2011).

In addition to positive environmental care, child character can also be formed through early childhood education (Davis \& Elliott, 2009; Degotardid \& Pearson, 2009). Character education given in schools aimed at children from an early age in order to be able to do acts of kindness through daily habits and learn to understand the moral and virtues. Blatchford (2009), revealed that the cultivation of the virtues can be instilled in children from an early age through early childhood education.

The importance of character building of children through parenting and early childhood education indicates that we need research seen from two main factors, namely, building the character of the child from the parental environment quality and from the environment in the school. This study aims to determine the effect of parental environment quality and early childhood education participation to the character of the child. This study also aims to analyze the differences in the quality of maternal nurturing environment and character of the child based on the participation of children in early childhood education.

\section{Research methods}

This study was a cross sectional study. Site selection was purposive in Bogor and Bogor City. The research was from June 2013 to August 2014. The study population was intact families in rural and urban areas that have the eldest child aged 36 years old living in one house in two selected areas. Framework sampling in this study was selected randomly. Total population in rural areas (village Urug, District Sukajaya, Regency, Bogor) was 104 respondents, while in urban areas (Situgede village, Bogor City) was 102 respondents. Based on the number of population in two selected villages, sampling was carried out according to formula Slovin (1960) so that there were 50 respondents taken in rural and in urban areas there were also 50 respondents, so the total respondents of this research was 100 respondents.

This type of data consists of primary data and secondary data. The primary data were obtained through interviews and observations of mothers and children with the tools questionnaire; (1) The characteristics of children (age and sex), (2) the characteristics of parent (age, length of education, per capita income, and family size), (3) the parental environment quality or HOME (Home Observation and Measurement of Environmental Inventory for Early Childhood) by Caldwell and Bradley (1984) with 55 items of questions, and (4) the child's character is measured using an instrument of 
approach character strengths by Peterson and Seligman (2004) and Lickona (1994) developed by the researchers consisting of six (6) dimensions, namely, wisdom, courage, humanity, justice, temperance, and transcendent. This is divided into three parts: knowing, feeling, and acting with 66 items of questions. Secondary data were obtained through the research area of demographic data.

Processing is done with Microsoft Excel and SPSS 16.0 for Windows. The quality control data used validity and reliability. To calculate questionnaire of parental environment quality, and the character of the child used a Likert scale by using the answer choices. Then the total score was transformed in index scores. The analysis in the study with descriptive and inferential analysis consisting of different test t-test and multiple linear regression tests were formulated as follows:

$\mathrm{Y}=\beta 1 \mathrm{X} 1 \beta 2 \mathrm{X} 2+++\beta 5 \mathrm{X} 5 \beta 4 \mathrm{X} 4 \beta 3 \mathrm{X} 3+++\beta 6 \mathrm{X} 6 \beta 22 \mathrm{X} 22 \ldots \ldots \ldots \ldots .++\mathrm{e}$

Information :

$\mathrm{Y}=\mathrm{a}$ child character

$\beta 1-22=$ regression coefficients; $\mathrm{X} 1, \mathrm{X} 2, \mathrm{X} 3, \ldots . . \mathrm{X} 22=$ free variables among others

(X1) $=$ child's gender $(0=$ female, $1=$ male $)$,

(X2) = the child's age (years),

(X3) = early childhood education participation,

(X4) = father's age (years),

(X5) = maternal age (years),

(X6) = how long mother's education (years),

(X7) $=$ status of working mothers $(0=$ not working, $1=$ working $)$,

(X8) = the number of family members (people),

(X9) = income per family (rupiah / month),

$(\mathrm{X} 10)=$ stimulation of learning (score)

$(\mathrm{X} 11)$ = language stimulation (score)

$(\mathrm{X} 12)=$ physical environment (score)

$(\mathrm{X} 13)=$ warmth and acceptance (score)

$(\mathrm{X} 14)=$ stimulation academic (score)

$(\mathrm{X} 15)=$ modeling $($ score $)$

$(\mathrm{X} 16)=$ variation stimulation $($ score $)$

$(\mathrm{X} 17)=$ punishment $($ score $)$

e $=$ error. 


\section{Result}

\section{Sample Characteristics and Family}

The average age of children who attend early childhood education was four years (4 years), while those who did not join the early childhood education were three years (3 years). Results of different t-test showed a significant difference between the child's age $(p<0.000)$ following early childhood education by not following early childhood education. The average age of the father (32.68 years old) and mother (26.62 years) whose child follows early childhood education is more mature than that of the father (30.10 years old) and mother (25.90 years) whose child did not follow the early childhood education.

Tabel 1 The minimum, maximum, average values, standard deviation and sample characteristics of the family

\begin{tabular}{|c|c|c|c|c|c|}
\hline \multirow{2}{*}{$\begin{array}{l}\text { Variable of Family } \\
\text { Characteristics }\end{array}$} & \multicolumn{2}{|c|}{ Follow ECE } & \multicolumn{2}{|c|}{ Not Following ECE } & \multirow{2}{*}{$\begin{array}{l}\text { T-test } \\
\text { (sig. 2- } \\
\text { tailed) }\end{array}$} \\
\hline & Min-Maks & Average \pm SD & Min-Maks & Average $\pm \mathrm{SD}$ & \\
\hline Child's age (Year) & $3-6$ & $4.8 \pm 1.042$ & $3-6$ & $3.8 \pm 0.935$ & $0.000 *$ \\
\hline Father's age (Year) & $24-80$ & $32.68 \pm 96.35$ & $20-63$ & $30.10 \pm 59.99$ & 0.103 \\
\hline Mother's age (Year) & $20-42$ & $26.62 \pm 47.11$ & $17-45$ & $25.90 \pm 52.71$ & 0.484 \\
\hline $\begin{array}{l}\text { Longer of father's } \\
\text { education (Year) }\end{array}$ & $0-12$ & $7.45 \pm 37.00$ & $2-16$ & $7.03 \pm 6.78$ & 0.575 \\
\hline $\begin{array}{l}\text { Longer of mother's } \\
\text { education (Year) }\end{array}$ & $2-13$ & $7.20 \pm 31.96$ & $0-16$ & $6.78 \pm 34.05$ & 0.541 \\
\hline $\begin{array}{l}\text { Number of families } \\
\text { (People) }\end{array}$ & $2-9$ & $3.85 \pm 13.31$ & $3-9$ & $4.18 \pm 15.68$ & 0.272 \\
\hline $\begin{array}{l}\text { Income per capita } \\
(\mathrm{Rp})\end{array}$ & $\begin{array}{c}66.667- \\
1.250 .000 \\
\end{array}$ & $\begin{array}{c}388.753 \pm \\
238.642 \\
\end{array}$ & $\begin{array}{c}100.000- \\
2.400 .000 \\
\end{array}$ & $\begin{array}{c}370.778 \pm \\
330.089 \\
\end{array}$ & 0.768 \\
\hline
\end{tabular}

There are fathers whose children follow early childhood education are in the older age groups advanced. The average length of education of the father (7.45 year) and mother (7.20 year) whose children follow early childhood education, longer than the father (7.03 years) and mother (6.78 years) whose children are not following the early childhood education (Table 1). Results of different t-test showed no significant differences between paternal age ( $p<0103)$, maternal age ( $p<0484)$, the long of father's education $(p<0575)$, and the long of maternal education $(p<0541)$ both of which follow or do not follow the early childhood education.

The average number of families who followed the example of early childhood education ( 3 people) was less than that whose child did not to follow early childhood education (4 people). The average per capita income families who followed the example of early childhood education ( $R p 388753)$ was greater than that of families who do not follow the example of early childhood education ( $R p 370778$ ) (Table 1). Results of different t-test showed no significant differences between the number of families ( $p$ $<0.272$ ) and a per capita income of the family ( $\mathrm{p}<0768$ ), whether or not to take early childhood education.

More than half the sample $(62.5 \%)$ following early childhood educa12tion was male, and a half $(55.0 \%)$ of the sample in which they did not follow early childhood 
education was also male. In general, the number of male respondents was higher than that of the female (Table 2).

Based on the status of working mothers, most mothers in this study did not work (75.3\%). Only a small proportion of working mothers in this study $(24.7 \%)$. Results of different t-test showed that there was no difference between mothers who work or who do not work in children who follow or children who do not follow the early childhood education (Table 2).

Tabel 2 Distribution of children according to gender and maternal employment status, and the participation in ECD

\begin{tabular}{|c|c|c|c|c|c|c|}
\hline \multirow[t]{3}{*}{ Gender } & \multicolumn{4}{|c|}{ Participation in ECD } & \multirow{2}{*}{\multicolumn{2}{|c|}{ Total }} \\
\hline & \multicolumn{2}{|c|}{ Follow ECD } & \multicolumn{2}{|c|}{ Not follow ECD } & & \\
\hline & $\mathrm{n}$ & $\%$ & $\mathrm{~N}$ & $\%$ & $\mathrm{~N}$ & $\%$ \\
\hline Male & 25 & 62.5 & 33 & 55.0 & 58 & 58.0 \\
\hline Female & 15 & 37.5 & 27 & 45.0 & 42 & 42.0 \\
\hline Total & 40 & 100.0 & 60 & 100.0 & 100 & 100.0 \\
\hline \multirow[t]{3}{*}{ Working status } & \multicolumn{4}{|c|}{ Participation in ECD } & \multirow{2}{*}{\multicolumn{2}{|c|}{ Total }} \\
\hline & \multicolumn{2}{|c|}{ Follow ECD } & \multicolumn{2}{|c|}{ Not follow ECD } & & \\
\hline & $\mathrm{n}$ & $\%$ & $\mathrm{~N}$ & $\%$ & $\mathrm{n}$ & $\%$ \\
\hline Working & 8 & 20.0 & 10 & 16.7 & 24.7 & 24.7 \\
\hline Not working & 32 & 80.0 & 50 & 83.3 & 75.3 & 75.3 \\
\hline Total & 40 & 100.0 & 60 & 100.0 & 100 & 100.0 \\
\hline Different t-test & \multicolumn{4}{|c|}{0.675} & & \\
\hline
\end{tabular}

The average score of the parental environment quality that does not follow the early childhood education (29.81) was higher than that of children who attend early childhood education (24.95). The result of different t-test showed a significant difference $(\mathrm{P}<0.027)$ between parental environment quality that does not follow the early childhood education (Table 3). If seen in every dimension of the parental environment quality, the dimensions of which have significant differences according to the result of different $t$-test showed that the stimulation of learning $(p<0.052)$ as well as the dimensions of academic stimulation ( $\mathrm{p}<0.030$ ).

Table 3 The Minimum, Maximum, Average Value, and standard deviation and parental environment quality .

\begin{tabular}{|c|c|c|c|}
\hline \multirow{2}{*}{ Parenting variable } & Follow ECD & Not follow ECD & \multirow{2}{*}{$\begin{array}{c}\text { Different t- } \\
\text { test } \\
\text { (sig. 2-tailed) }\end{array}$} \\
\hline & Average \pm SD & Average \pm SD & \\
\hline \multicolumn{4}{|c|}{ Parental environment quality (HOME) } \\
\hline Stimulation of learning & $54.09 \pm 17.58$ & $61.96 \pm 20.80$ & $0.052 *$ \\
\hline Stimulation of languages & $2.14 \pm 5.16$ & $7.61 \pm 18.12$ & 0.066 \\
\hline The physical environment & $29.28 \pm 26.47$ & $28.09 \pm 28.07$ & 0.832 \\
\hline The warmth and acceptance & $16.42 \pm 26.58$ & $24.28 \pm 32.13$ & 0.203 \\
\hline Stimulation of academic & $5.50 \pm 11.08$ & $14.33 \pm 23.60$ & $0.030 *$ \\
\hline Modeling & $22.50 \pm 15.81$ & $22.67 \pm 21.30$ & 0.966 \\
\hline variations stimulus & $30.27 \pm 21.78$ & $33.70 \pm 17.71$ & 0.390 \\
\hline Punishment & $7.50 \pm 18.94$ & $12.50 \pm 23.69$ & 0.267 \\
\hline Total HOME & $24.95 \pm 9.19$ & $29.81 \pm 11.45$ & $0.027 *$ \\
\hline
\end{tabular}

$* *$ significantly on $\mathrm{p} \leq 0.01, *$ significantly on $\mathrm{p} \leq 0.05$ 


\section{Child's Character}

Based on the dimensions of the child's character seen in table 4, the dimension of wisdom and knowledge shows that the average score of children who attended early childhood education (83.75) was higher than the average scores of children who did not follow the early childhood education (71.54). The different t-test showed a significant difference $(\mathrm{P}<0.011)$ between the average score of the characters on the dimensions of wisdom and knowledge to the children who attended early childhood education and children who did not follow the early childhood education. The average score on the dimension of the courage of children who attended early childhood education (77.60) was higher than children who did not follow the early childhood education (63.40). The different t-test showed a significant difference $(\mathrm{P}<0.008)$ between the average scores of characters in dimension courage of children who attended early childhood education and children who did not follow the early childhood education.

Table 4 The minimum value, maximum, average, and standard deviation of the child's character.

\begin{tabular}{|c|c|c|c|}
\hline Character & $\begin{array}{c}\text { Follow ECD } \\
\text { Average } \pm \text { SD }\end{array}$ & $\frac{\text { Not follow ECD }}{\text { Average } \pm \text { SD }}$ & $\begin{array}{c}\text { Different t-test } \\
\text { (sig. 2-tailed) }\end{array}$ \\
\hline Wisdom & $83.75 \pm 21.24$ & $71.54 \pm 24.59$ & $0.011^{*}$ \\
\hline a. Open mindedness & $77.91 \pm 21.76$ & $62.63 \pm 28.43$ & \\
\hline b. Love of learning & $89.56 \pm 22.86$ & $80.27 \pm 23.41$ & \\
\hline Courage & $77.60 \pm 24.97$ & $63.40 \pm 26.43$ & $0.008 *$ \\
\hline a. Persistence & $82.70 \pm 24.70$ & $66.80 \pm 27.93$ & \\
\hline b. Integrity & $72.50 \pm 27.36$ & $60.00 \pm 28.48$ & \\
\hline Humanity & $26.66 \pm 14.05$ & $28.66 \pm 12.38$ & 0.455 \\
\hline a. Love & $77.29 \pm 29.89$ & $65.52 \pm 30.14$ & \\
\hline b. Kindness & $72.29 \pm 31.71$ & $56.52 \pm 30.14$ & \\
\hline Justice & $76.77 \pm 31.78$ & $55.76 \pm 31.35$ & $0.002 *$ \\
\hline a. Equality & $79.37 \pm 30.07$ & $61.80 \pm 30.92$ & \\
\hline b. Leadership & $74.16 \pm 35.29$ & $49.72 \pm 35.45$ & \\
\hline Temperance & $74.02 \pm 33.33$ & $57.22 \pm 31.56$ & $0.014 *$ \\
\hline a. Prudence & $75.20 \pm 87.50$ & $59.44 \pm 32.52$ & \\
\hline b. Self-control & $71.67 \pm 36.63$ & $52.77 \pm 36.32$ & \\
\hline Trancendens & $70.41 \pm 29.51$ & $52.59 \pm 60.75$ & $0.004 *$ \\
\hline a. Gratitude & $72.91 \pm 29.64$ & $53.33 \pm 31.56$ & \\
\hline b. Spirituality & $69.16 \pm 30.55$ & $52.22 \pm 30.68$ & \\
\hline Total Character & $76.59 \pm 26.35$ & $60.75 \pm 26.27$ & $0.004 *$ \\
\hline Knowing & $80.96 \pm 31.64$ & $61.74 \pm 35.53$ & $0.007 *$ \\
\hline Feeling & $62.84 \pm 32.70$ & $44.35 \pm 31.52$ & $0.006^{*}$ \\
\hline Acting & $85.96 \pm 20.84$ & $76.17 \pm 19.57$ & $0.019 *$ \\
\hline
\end{tabular}

The average score on the humanity dimension of children who attended early childhood education (26.66) was lower than children who did not follow the early childhood education (28.66). The different t-test showed no significant differences ( $P$ $<0.455)$ for humanity dimensions between the children who attended early childhood education and children who did not follow the early childhood education. The average score of justice dimension on children who attended early childhood education (76.77) was higher than children who did not follow the early childhood education (55.76). The different $t$-test showed a significant difference $(P<0.002)$ for the dimension of justice 
among children followed the early childhood education and children who did not follow the early childhood education (Table 4).

The average score on the dimensions of the temperament of children who attended early childhood education (74.02) was higher than children who did not follow the early childhood education (57.22). The different t-test showed a significant difference $(\mathrm{P}<0.014)$ for the dimensions of the temperament of the children who attended the children who attended early childhood education to children who did not follow the early childhood. Then the average score on the dimension of transcendence children who attended early childhood education (70.41) was higher than children who did not follow the early childhood education (52.59). The different t-test showed a significant difference $(\mathrm{P}<0.004)$ for the dimension of transcendence among children who attended early childhood education to children who did not follow the early childhood education (Table 4).

The results showed that the average score of knowledge (knowing) children who attended early childhood education (80.96) was higher than children who did not follow the early childhood education (61.74). The different t-test showed a significant difference $(\mathrm{P}<0.007)$ between the mean score of knowledge related to the character of the children who attended and who did not follow the early childhood education. On an average score of feeling of children who attended early childhood education (62.84) was higher than children who did not follow the early childhood education (44.35). The different $t$-test showed a significant difference $(\mathrm{P}<0.006)$ between the average scores of children's feeling who attended the early childhood education that did not follow early childhood education. The average score of the children's acting who attended early childhood education (85.96) was higher than children who did not follow the early childhood education (76.17). The different t-test showed a significant difference $(\mathrm{P}$ $<0.019)$ between the characters' actions with the children who attended early childhood education and did not follow the early childhood education (Table 4).

\section{Variables Affecting Children Character}

There are variables that affect the child's character. The influence of the characteristics of the child (gender, age, participation of early childhood education) and family characteristics (paternal age, maternal age, length of mother's education, the status of working mothers, family size, income per capita), as well as the parental environment quality analyzed by linear regression multiple (Table 5). Models built have a coefficient of determination (Adjusted R Square) of 0.323. The coefficients showed that 32.3 percent of the child's character was influenced by changes in the variables in this model, while the remaining 67.7 percent was influenced by other variables examined in this study. The results of multiple regression analysis at $p \leq 0.10$ showed that the variables of sex, age, maternal age, maternal employment status, and academic stimulation significantly affected the character of children (Table 5). 
Table 5 The results of multiple linear regression analysis of variables that affect the child's character.

\begin{tabular}{|c|c|c|c|c|c|}
\hline \multirow{2}{*}{ No } & \multirow{2}{*}{ Variable } & \multicolumn{3}{|c|}{ Coefficient } & \multirow{2}{*}{ Sig. } \\
\hline & & $\mathrm{B}$ & Std. Error & Beta & \\
\hline 1 & $\begin{array}{l}\text { Child gender } \\
\text { (female }=0, \text { male }=1 \text { ) }\end{array}$ & -13.045 & 5.412 & -.237 & $0.018^{*}$ \\
\hline 2 & Child's age (year) & 13.886 & 2.857 & .555 & $0.000^{* *}$ \\
\hline 3 & $\begin{array}{l}\text { Participation on ECE } \\
(\text { Not follow }=0, \text { follow }=1)\end{array}$ & 4.162 & 5.699 & .075 & 0.467 \\
\hline 4 & Father's age (year) & -.520 & .377 & -.147 & 0.172 \\
\hline 5 & Mother's age (year) & 1.532 & .620 & .283 & $0.016^{*}$ \\
\hline 6 & Longer of mother's education (Year) & 1.556 & .962 & .189 & 0.110 \\
\hline 7 & $\begin{array}{l}\text { Maternal employment status (not } \\
\text { working }=0 \text {, working }=1 \text { ) }\end{array}$ & -11.036 & 5.689 & -.198 & $0.056^{*}$ \\
\hline 8 & Number of families (People) & -.519 & 1.788 & -.028 & 0.773 \\
\hline 9 & Income per capita (Rp) & $-5.420 \mathrm{E}-6$ & .000 & -.059 & 0.525 \\
\hline 10 & Stimulation of learning (Score ) & -.066 & .159 & -.048 & 0.678 \\
\hline 11 & Stimulation of languages (Score ) & -.175 & .173 & -.094 & 0.315 \\
\hline 12 & The physical environment (Score ) & .071 & .089 & .071 & 0.430 \\
\hline 13 & The warmth and acceptance (Score ) & .061 & .101 & .067 & 0.552 \\
\hline 14 & Stimulation of academic (Score ) & .227 & .127 & .166 & $0.079 *$ \\
\hline 15 & Modeling (Score ) & -.187 & .148 & -.132 & 0.209 \\
\hline 16 & Variations stimulus (Score ) & .157 & .128 & .112 & 0.224 \\
\hline 17 & Punishment (Score) & .081 & .115 & .065 & 0.484 \\
\hline \multirow{2}{*}{\multicolumn{2}{|c|}{$\frac{\mathrm{F} \text { Test }(\mathrm{p})}{\text { Adjusted } R \text { Square }(\mathrm{df} / \mathrm{n})}$}} & & \multicolumn{3}{|c|}{$3.784(0.000)$} \\
\hline & & & & $3(17 / 10$ & \\
\hline
\end{tabular}

\section{Discussion}

The results showed that the quality of parenting environment was better in mothers whose children did not follow early childhood education. Nurturing environment that was stiffened by the mothers of children who did not follow the early childhood education had a quality of care that was good in dimensional stimulation of learning, language stimulation, warmth and acceptance of the mother to the child, stimulation of academic, modeling, abd how a mother gave a variation stimulation and the implementation of positive punishment. This is presumably because the mother who had already engaged their children in early childhood education had decreased in stimulating children's education at home and handed the child to the school education. This is in line with the results of Agung (2014), the low participation of parents in early childhood education was caused by the lack of time, materials, and low parental education. The results showed that the child's gender and age of the child related to the child's character. This is consistent with the results of other studies that reveal that the gender of the child and the increasing age of the child are significantly affecting the development of children's character (Hastuti \& Alfiasari 2008).

Based on the regression test, it shows that the influence of gender, age, maternal age, maternal employment status, and parental environment quality on the dimension of academic stimulation affected the character building of children in early age. According to Hastuti and Alfiasari (2008) gender of the child and child's age increase significantly 
affect the development of children's character. Then, according to Holden (2010), the moral development of children during early childhood for girls is better than boys because of factors of social maturity of girls that is earlier than boys, but the subsequent development of them requires stimulation developments with same good moral which must be able to develop the character into adulthood. Children have a moral basis of good character since he was born, while the increasing age of the child will have a maturity of overall development so that development of the character would also be better with age (Bloom, 2013; Megawangi \& Hastuti 2005). Then the mother who has more mature age is expected to have a wider knowledge including knowledge in parenting and the formation of character (Papalia et al. 2009). In this research, working mothers have a low education or did not complete primary education, thus allegedly working mothers in addition to having limitation of time; they also have limitations in terms of knowledge of early childhood stimulation. According to Chang (2010) parental education related to child development.

Based on the results of the regression analysis, early childhood education participation did not affect the development of children's character. The participation in this study only looked at whether the child attended early childhood education based on presence children in school, while there were other factors in addition to the participation of quality in early childhood education that also needs to know to see more optimal child development, especially for the development of children's character. According to Essa (2011), the quality of early childhood education viewed from a variety of ways, one of which is the implementation of the program which is worth. Implementation of the program is worth in this case related to how teachers implement character education and internalized it on the daily activities of children in school. Effective character education in schools also involves creating a kind of classroom and school environment that allows all students, without exception, to realize their potential to achieve important objectives, namely child character (Battistich 2011). Kangas (2016) also confirms that children's participation in early childhood education also needs to be seen in the aspect of how children actively participate in learning activities in the classroom during the learning process so that in this study, the participation of children seen only on school attendance had no effect on the character building. There were many factors affecting the quality of early childhood education in school so that they could influence the development in children's character.

Research results showed that the influence of environmental quality of parenting on the dimension of academic stimulation affected the character of the child. It confirms the importance of the mother's role in shaping the character of children from an early age through good quality parenting environment. This is consistent with results of previous studies in which the stimulation of the child's environment related to child development (Chang 2010). The study also revealed that the quality of good parenting environment can reduce behavioral problems at an early age (Sektan et al, 2010). 


\section{Conclusion and suggestion}

\section{Conclusion}

There are differences between the environmental quality of parenting whose child attended early childhood education to children who did not follow the early childhood education. Parental environment quality in which children did not follow the early childhood education was better than that following the early childhood education. Factors that influenced the character of children were gender, age, maternal age, maternal employment status, and academic stimulation (dimensions on environmental quality mothering). Children's participation factors in early childhood education did not affect the character of the child.

\section{Suggestion}

It is necessary to have counseling on the importance of positive parenting, particularly on the environmental quality of parenting for older people who have put their children in early childhood education. Then the importance of assistance to working mothers who have low levels of education to be able to optimally provide good parenting on children so that the character development of children can be better. It is advised to do further research to investigate the care and quality of early childhood education on the various dimensions of quality in early childhood education and participation by children activity in the class so as to determine the output children development with better character.

\section{Acknowledgment}

Further thanks to the Research Team Decentralization seeded College in 2013; Alfiasari SP, M.Sc., Dr. Ir. Dwi Hastuti, M.Sc., and Ir. M.D Djamaludin, M.Sc.

\section{Reference}

Agung T. 2014. Participation of Parents in Early Childhood Education. [Thesis]. Indonesian Education University. http://repository.upi.edu/.[11 Agustus 2014].

Battistich V. 2011. Character Education, Prevention, and Positive Youth Development. http://www.character.org/wp.content/uploads/2011/12/White Paper_Battistich.pdf [11 Oktober 2016].

Bhat, A., \& Aminabhavi, V. (2011). Home Environment and Psychosocial competence of Adolescents. Journal of Psychology, 2(1), 57-63. Retrieved from http://www.krepublishers.com/02-Journals/JP. [10 oktober 2016].

Blatchford, J.S. 2009. Education For Sustainable Development In Early Childhood. International Journal of Early Childhood, Vol. 41, No. 2, 2009. http://OmepOng.Net. [15 Desember 2014] 
Bloom, P. 2013. The Moral Life of Baby. http:// www.ccientificamerican.com/article/the-moral-life-of-babies/. $\quad[17 \quad$ Febuari 2013].

The Central Statistics Agency [BPS]. 2014 Crime Statistics 2014. ISSN 2089.5291. http://bps.go.id.

Chang, C.M. 2010. Images of Early Childhood Development in Indonesia. Jakarta (DI): Education Unit of the World Bank office in Jakarta.

Davis J, Elliott S. 2009. The preschool child of today - the world-citizen of tomorrow? International Journal of Early Childhood, Vol. 41, No. 2, 2009. USA: World Organisation for Early Childhood Education.

Degotardid S, Pearson E. 2009. Early Childhood Education for Sustainability: Recommendations for development. International Journal of Early Childhood, Vol. 41, No. 2, 2009. USA (US): World Organisation for Early Childhood Education.

Essa, E.L. 2011. Early Childhood Education .USA (US):Wadsworth.

Hastuti D, Alfiasari. 2008. Psychosocial Stimulation and Its Effect on the Characters Children who attend school and did not attend school at Children's Playground Semai Seed Nation, North Aceh District, Aceh Province. Journal of Family and Consumer Sciences, Volume 1 No. 2 in 2008.

Holden GW. 2010. Parenting: (88-104). California. (US): SAGE Pub. Inc.

Kangas J. 2016. Enhancing Children's Participation in Early Childhood Education Trough The Partisipatory Pedagogy. ISBN 978-951-51-1833-2. http://helda.helsinki.file PDF.[8 Oktober 2016].

Megawangi R. 2009. Character Education. Third edition. Jakarta (ID): Gapprint.

Papalia DE, Olds SW, Feldman RD. 2009. Human Development tenth Edition. Marswendsdy B. Translators; Widyaningrum. Editor. Jakarta: Publisher Salemba Humanika. Translation Of Human Development 10th Ed.

Sektan, M., McClelland, M.M., Acock, A., Morrison, F.J. (2010). Relations between early family risk, children's behavioural regulation, and academic achievement. Early Child Research Quarterly. 2010; 25: 464-479. DOI: $10.1016 /$ j.ecresq.2010.02.005. 